\title{
Positive Paradigm As The Barrier of Art Creativity Interpretation
}

\author{
Susilo Pradoko \\ Department of Arts, Drama, Dance and Music, Faculty Languages and Arts, \\ Universitas Negeri Yogyakarta, Indonesia
}

Submitted: August 19, 2019. Revised: November 4, 2019. Accepted: December 28, 2019

\begin{abstract}
In the modern era, during the end of 17 century, appears empiric paradigm in the philosophy field. This paradigm emerges due to the critic towards mythical social thought. The next step appears positivism thought by Auguste Comte in 1830, which stated that Sociology based on science analogy that can be learned in the form of empiric data with exact calculation; out of this is rated as not scientific. The education field also trails the modern thought tradition, along with Comte's positivistic thought. This modern era eventually has been opposed by postmodern philosophers. The frailties in the modern era are criticized by the appearance of the postmodern paradigm. Positivistic thought, in reality, could not reveal study beyond human and society, because this study is strong, and can only reach the ontologic stage, in substance of the object. While this could not be revealed because its level involves human and society's way of thinking, primordial, tradition, and historical aspects, this study focuses on the weaknesses of positivistic research. Then it will present post-positivistic-postmodern research through Hermeneutika and Foucauldian Genealogy research.
\end{abstract}

Keywords: Positivism; Creativity; Interpretation; Hermeneutics; Foucauldian Genealogy

How to Cite: Pradoko, S. (2019). Positive Paradigm As The Barrier of Art Creativity Interpretation. Harmonia: Journal of Arts Research And Education, 19(2), 133-140.

\section{INTRODUCTION}

Positivism is a study of how to get ideas based on empiric fact. Positivism paradigm appears and puts critics to the scientific tradition which relies on metaphysics, science requisite by thought processes, Foucauldian study only. In the history of the human culture stage inline with the present ontological culture stage, if we borrow the culture stage model from Van-Peursen is the Ontology Cultural Stage, the human takes a space to everything he used to feel as a siege. Puersen starts to arrange a theory or theory about the substance of everything (ontology) and the specification. (Van-Peursen, 1988). Human is no more bounded by mystical power or invisible power. Thus, the positivistic paradigm is the critic of scientific achievement based on supernatural power and metaphysical concepts with no empirical fact in theology. Poespowardojo said about positivism idea as follow:

".... positivism is a vision that natural science is the only empiric source. Speculative intelligence activity creates unproved statements empirically, and this area is not scientific because it can not be proven empirically, right or wrong. So, positivism focuses on experience and free willingness. Experience is provable sensory data; if it is not, we can not say it

\footnotetext{
${ }^{\square}$ Corresponding author:

E-mail: susilo_pradoko@uny.ac.id
} 
is as a fact" (Poespowardojo, 2015).

The positive paradigm appearance was rejection against the science which is a logical abstraction, ideas and affected by invisible powers, mistic. This appearance is a critic towards metaphysics and mythology culture stage, responding to universe and power rated to have spirits or mith story for solving unanswered nature phenomena at that time (Pradoko, 2015). In a study, fact concept usually connected with reality concept. (especially in the social study) and objectivity. Many people think the meaning of truth is clear and completely exist in their mind. This turns most scientists believe that their knowledge is exactly due to the provable fact. (Sumartono, 2017). Ideas considered as scientific if it is provable empirically visible and concreate through human sense, then these facts supported by mathematical calculation will be the background of quantitative research. In a positive stage, human leaves a metaphysical way of thinking. They restrict themselves to positive science; it is the science-based on fact. Only in this stage law with provable through experiment can be created. (Sumartono, 2017).

In this modern era, a theory is raised, that an absolutely correct science is one which based on laboratory work. It is empirical experience or empiricism belief. Belief and estimation are not scientific. Human knowledge resource about the world is evidence of our sense. Empirical community declares that the absolute fact is the one we can see through empirical sight. (Benton, 2001). The postmodern philosophers criticize the weakness of the modern world which has positivistic quantification background. It pops out social humanism research thinkers who trace the fact behind empirical facts seen in the society. These speculations create research models which is expected to dig deep behind the spectacle reality, reveal it beyond and in-depth.

The modern era which criticizes mythical era idea has passed. Now is the postmodern that criticizes the modern thought pattern. Philosophers have criticized modern thought by explaining the philoso- phical base with which will be actualized into the background of society's study and education field. Hence, the education field seems to be stupified by the glory of the modern era with the empirical philosophy concept and actualized in Auguste Comte positivism study. This study will present the chains of positivistic research in education and art. So it is expected that education society falls into its own rational instrument. The discussion part will give an example of research results that can reveal the empirical reality and beyond society. There are plenty of studies categorized as a postmodern paradigm. However, the researcher will only focus on the kind of Paul Ricoeur Hermeneutika study and Foucauldian Geneology Study.

\section{METHOD}

Auguste Comte's positivism theory is based on empiric philosophy and natural science tradition which can solve life problems related to the natural environment where human lives. The universe, mountain, and forest are no more frightening for humans with mystical stories, god and goddess, also spirits. Nature is an object whilst human is the subject; this speculation underlined natural sciences and physics. Human as a subject who manages and observe while nature is as an object which is being managed and observed. This speculation also underlies the positivistic quantification study method. The laws of exact science and the paradigm procedures in observing humans are adopted and implemented for humans as well. This thought has a consequence that observed human turns into the object like nature thing. The way to treat and the study instrument products will be adjusted like natural science experiment procedure.

Education study is still stuck to modern positivism research, and it affects the students, college students. They are considered as the object. It is the weakness need to concerned. In the study related to material things and technology, media is properly used in the positivistic study. The 
student is not likely non-living thing treated as an object. If it is not developed with postmodern philosophy, it turns into a robotic system. Children will be treated as a robot. The relationship that will occur is the researcher as the subject and children as the object. The observed student has no fair position; they will only follow the provided rules from the researcher. Meanwhile, post positivistic criticizes and tries to improve this case with philosophical paradigms that end with steps of socio-humanism research.

Dilthey sees antithesis if the pattern of Geistewissenchaften (re: natural science method) could be implemented in understanding mental life and human experience. The dynamics of human mental life in the shape of a complex arrangement of knowledge, feeling and willingness and could not be ruled in the causality of norms and inflexible mechanistic thought using the quantitative pattern. Geistewissenchaften (re: natural science method) understands this life through formulas category from the inside (intrinsic category). Life is a human experience seen from inside. Life should be counted from the experience of interpreting its ownself. It does not only form the theory and scientific knowledge, but a critical history ratio also is not a real critic. We understand ourselves, not through introspection but history. Human needs different interpretation model from nature occurrence model. It is a different paradigm. (Poespoprodjo, 2004)

Study with post positivistic paradigm is quite plenty nowadays: hermeneutic, phenomenology, ethnography, post positivistic structuralism, structuration, Perce semiotics, Roland Barthes semiotics, deconstructions, critical discourse analysis, and foucault genealogy analysis. This research will only present two reasearch methods with postpositivism paradigm. They are Hermeneutika Paul Ricoeur and Faocauldian genealogy discourse analysis.

Hermeneutics is the study about interpretation, an interpretation process to understand the source of the problem, to understand that a researcher should be "there," in the area of his research. Understanding the field of Hermeneutics is an action word which has a wide range of explanation. It can solve many aspects of the problem and explain all unclear aspects into the clearer one (Pradoko, 2015). Deep understanding means able to reveal by producing deep descriptions toward the object of the research. For instance, a forensic painter expert in USA could draw the criminal face precisely. He draws based on the story told by the victim. What was told caught in depth by the drawer so it will produce precisely the criminal precise image? Referring the expert's picture, the police have caught 100 criminals.

Paul Ricoeur Hermeneutical Analysis for research text in language can be used for material art phenomenon research. The diagram for interpreting a text in many connected contexts is presented as follow:

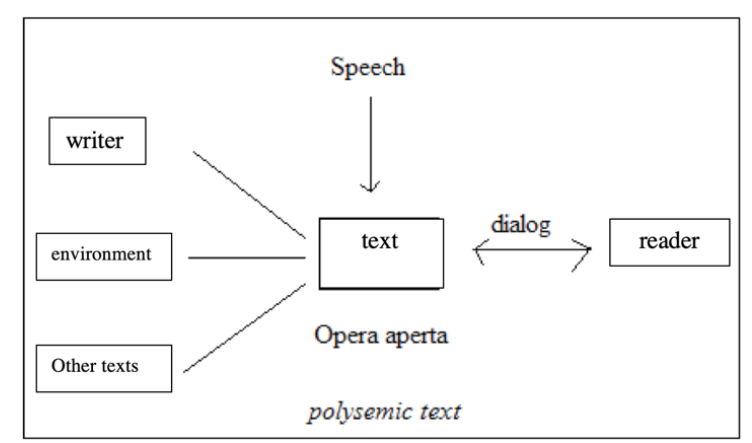

Figure 1. Polysemical Text Diagram (Source Hoed, 2011)

The Ricoeur's idea about text interpretation can be used in studying social phenomenon object in art material practice and literature resource about it. We change the text with social phenomenon object in art material. The context we need to consider is the researcher, in this case, refers to the artist. The environment is the supporting society that lives and lives the art material object. Society ethnic inhabit the area and geographics environment where society lives. Another text is theories connected with the social phenomena of cultural art objects being studied and the literature source about it. Reader in this term 
is the researcher himself and artist experiences as an object, and artists living in that area (Figure 2).

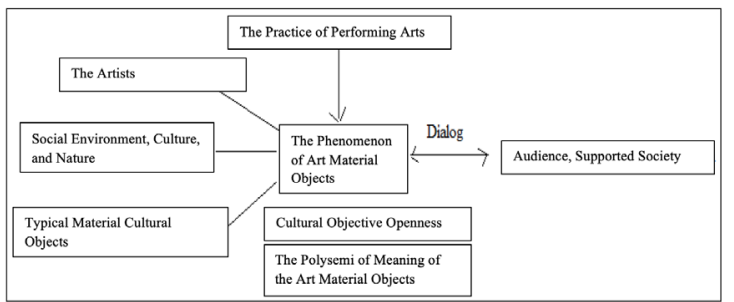

Figure 2. The understanding of Hermeneutical text process by Paul Ricoeur implemented in art material object phenomenon

In a text, meaning study turns into art material phenomenon, considered context for the sharp of art phenomenon analysis is practice of art in local society suitable with research area, artist, natural environment, social and culture, cultural knowledge, another material outside of research range, dialectical relation among researchers, spectators, artists, and supporting society to the material art subject. Various context problems to solve a social material art object phenomena will allow understanding and better result interpretation, and the detail on doing context to many aspects produce holistic and profound research.

Research shows that invisible is revealing, analyzing ideas. This idea could not be seen in a glace. It needs an analysis, searched to find the expression and evidence-based on the experienced and observed. This research can be conducted by the archeology method with Foucauldian genealogy analysis system.

Genealogy, as Foucault to study about history through discourse analysis and to observe not who owns power but how the authority rolled through interaction. (Kholifah, 2018)

Foucault Genealogy is likely history draws kinds of the science field, discourse, and objects. This history does not create the meaning based on causal continuity which leads to telos. In fact, genealogy is a historical continuity disconnection (rapture) stated as wirkungsgeschicte (effective history) by Gadamer. History in Foucault is no historical subject. It is a historian and reminder society, disconnection, subject eradication itself happens because subjectivity will lead to domination (Hardiman, 2003; Kali, 2013). Genealogy, as the searching of origin, genealogy of idea, genealogy tries to seek the depth of episteme and put the fact fundamental in each epism in every stage (Kali, 2013).

Michel Foucault presents the process base to study discourse in historical through 4 stages, they are: Discontinuity arrangement in history, ideas are categorized which element is suitable for each arrangement. The next step is to determine the border of how this specific relation types. The process continued by describing among different arrangements and designing part by part.

Discontinuity study is done in 3 ways: Having prediction enables us to look for level analysis possibility and time periodization at each level; Looking for direction distortion from a constant movement or end of the pendulum movement. In short, discontinuity is the moment where the causality cycle paralyzed; Discontinuity personalizes a form, and specific function depends on the historical stage being conducted by the historian.

The absence of total historical union into new history talks about division, borders, level differences, movement, chronological explanation, particular forms of various rehandling forms of events, and relation type possibility.

A new history from archeology idea knowledge system immerses six consequences: Corpora are forming from coherence documents and homogeneity; Principal forming about element choices analysis; Defining the analysis level of relevance element; Typical characteristics analysis method, complexity factors based on analyzed differences; Group limitation and sub group from analyzed elements; Relations certainty possible to put character to a group (Foucault, 1976). 


\section{RESULTS AND DISCUSSION}

Auguste Comte brings positive idea based on empirical observation through laboratory model is a piece of real evidence visible, observable, touchable, and countable. This is what he calls a positive idea for constructing social hegemony. The science is known as social physics or sociology. An unprovable idea empirically is considered unscientific. The characteristics of science are as follows: (1) Empirical calculation in science is accepted. (2) Science considered as the highest knowledge with the condition that is passing the modern empirical paradigm. (3) A Scientific method with empirical study implemented in human social life as firm sociology. (4) Social scientific ideas can be implemented to control the individual and society. Social problems and conflict can be defined and solved one by one with expert skill similar science experts involved in solving engineering technology. This social scientific project is known as social engineering.

Empirical positivistic research is not appropriate for research which aims to uncover human thinking and let alone artistic creativity. Besides having a visible physical appearance, humans also have invisible thoughts processed in the brain system which has data and networks in a primordial way. Humans have been complete since they were born until adulthood; it is bound by the cultural contextual where humans exist. Empirical research is only able to see the basic surface without being able to uncover beyond existing thoughts in humans. Like we examine a wedding ring, empiricists will only be able to physically examine the ring. According to the positivistic thinking of the paradigm proposed by Benton and Graib, the things to be examined will be about: What is the diameter, radius of the wedding ring circle? What color is the ring? How many grams does the ring weigh? What chemicals are the rings mixing? How many carats of gold content does it contain? What is the current price of the wedding ring?

The weaknesses of calculative positi- vistic research are that they cannot penetrate historical aspects. Physical research at the time of the study being viewed. When it is in contact with humans, physical material will no longer be answered by positivistic research methods. For example is the wedding ring, when it is connected with human thought, it will be more complex and very relative. Girl A was married with a 5-gram ring weighing 24-carat gold at the price of buying 3.5 million. After getting married for four months the ring was wanted by someone for 7 million but was not given. On the other hand, girl $\mathrm{B}$, when married, had 3.5 million-ring from her bridegroom. After getting married for four months, the wedding ring reminded her for nothing but sadness, so it was worthless to her, the ring became a sign of suffering for her. This is the example of social sciences must have their methods. The point of all that is positivistic science needs to be refined with other types of research for the children of this nation, especially in the world of art education.

Humans are not robots; positivistic research starts from research in the natural sciences which are inanimate objects, objects that are considered unable to communicate with humans. Positivistic research is research that has a philosophical paradigm of objectivities, nature as objects freely treated by humans. This logic is not appropriate for students, especially students in the arts. Humans are not inanimate objects, so humans must be seen as fellow-subjects. Positivistic research that dominates the research methods, media, and student-teacher interaction needs to be reconsidered, or at least developed, to explore inter-subject research, not subject and object research. During the research, which glorifying the paradigm of the subject and object, students will be formed as robots. This kind of research never, in-depth, studies the construction of children's thinking, what construction is needed for children and what is actually their creativity and independence. Researches that objectify students will cause a lack of excavation in students' reasoning 
and student creativity. One example in experimental research, students didn't have their bargaining position as they were treated like objects.

Humans exist in this world, ontologically and ontically. Ontological means the nature of being seen by the physical body. Ontic is being seen from the primordial historical aspects that are inherently contextually integrated with the axiological traditions experienced in their cultural environment. Ontologically, the human body is often examined using positivistic empirical research methods. While the primordial ontic reach of human thought, in the context of cultural values, will be unreachable only by quantitative-empirical research. Many things of human thought with its cultural complexity do not necessarily appear in research expressions. Human thoughts and culture must be explored with research methods that do reveal the realm of human ontic. An alternative to answering the problem is by conducting studies that can reveal beyond begins with the signs that are expressed. Two examples of revealing beyond research are Paul Ricoeur's hermeneutics research and archeological discourse analysis of thought studies with genealogy by Michel Foucault.

Research revealing the empirical facts behind the text as an example in this paper is the research by Sulastri with her supervisor, A.M.Susilo Pradoko, entitled: " Review of Berita Kepada Kawan by Ebiet G.Ade's Work from a Hermeneutic Perspective." To summarize, the purpose of research in number 3 was to reveal the denotative meaning contained in the song Berita Kepada Kawan. In number 4, it reveals the connotative meaning contained in the song Berita Kepada Kawan.

The results of the research of the denotative meaning of the song are about someone who tells the story of his lonely journey to a disastrous place. The result of connotative meaning is someone who sympathizes and empathizes with a natural disaster that befell his homeland. The person helped the victims of the disaster in various ways, but unfortunately, no one cared, so the person was annoyed. In the end, the person sees the disaster as an indicator of self-introspection and helps him to keep on remembering his creator (Sulastri, 2016). The process of searching for connotative meaning is carried out with various aspects, as has been described in the chart Paul Ricoeur used to study the text and then adopted by revealing the art phenomenon/art material.

Research of song meaning that doesn't implicitly appear in its poetry is also conducted by Ayu Rachma Purnama Sari, a thesis with A. M. Susilo Pradoko as the supervisor. The title of the research is: "Educative Values and Implementation of the Senjang Petuoh Lame Song at Sanggar Senjang Budayo Sekayu, Musi Banyuasin Regency, South Sumatra Province". After conducting the research by using hermeneutic analysis of Paul Ricoeur, revealing the denotative and connotative meaning of the text as well as doing ethnography in his society, the results of the study showed that the song of the lunar gaps is closely related to the culture of the people. The song has meaning: manners, hard work, responsibility, friendliness, divinity, discipline, and prohibition of drugs (Purnamasari, 2018). The meaning of the song values has also been implemented in concrete actions at Sanggar Senjang Budayo Sekayu, Musi Banyuasin Regency in which the study of implementation was strengthened through ethnographic observation.

In the applied example of this paper, the object of study will be a material culture in the form of the Ramayana Relief at Prambanan Temple from 856 AD to the 1996 or IX century to XX century. The following research reveals the archaeological meaning of epistemology of thought regarding the influence of Hindu power, the influence of Islamic power, the influence of colonial power and the influence of independence in responding to material culture in the form of Relief Ramayana Prambanan Temple. After conducting this Foucauldian-genealogy-based research, we get archeology of thought that differs 
between the periods of power.

Fundamental ideas in every period affect the point of view material culture art object in the form of different Ramayana engravings, occurrence of ideas system episteme which can be tracked in depth in every gap. Ideas archeology invention gap in its fragmentation enriches the encyclopedia and use for different fundamental ideas. In analogical terms, although this study put archeology in Ramayana Engraving as an example, but this archeology Foucault model can also be applied for other art like theatre study, dance, music, even for tangible and intangible cultural study.

The study of cultural meaning problem of tangible and intangible is not directly visible in physics empirical form. Meaning is in the form of denotative and connotative. Connotative meaning needs more detail assisted by paradigms or sharp analysis knife to reveal the meaning behind the shown cultural phenomenon. This study is not enough with empirical positivistic. The hypothesis empiric quantification is not adequate to reveal beyond behind the society art phenomenon. Study towards humans equalized with instrumental regulation towards natural things is no more adequate in the context of completely humanizing.

Development of education research and intersubjective paradigm humanity among researchers need to be developed to create an undivided human, not a robotic one. Study to dig children's creativity, children's way of thinking, teacher's way of thinking to react to science and all environment aspects should be improved by the improvement of the post positivistic paradigm research method; it is postmodern. The study of constructivist research in children, ways of thinking, critical thinking processes, critical literacy research, until deconstruction research ends in appreciation of the "other." This can be observed and respected as a friend or subject so that the position is the same. In Javanese, he said nguwongke uwong, means to humanize humans.

\section{CONCLUSION}

Auguste Comte positivism ideas are based on empiric philosophy, and natu-

\begin{tabular}{|c|c|c|c|}
\hline \multicolumn{4}{|c|}{ Table 1. Science Archelogy 856-1988 } \\
\hline & Ideas of $\mathrm{A}$ & eology of Prambanan & Temple Relief \\
\hline $\begin{array}{l}\text { Hinduism Era: } \\
\text { (856-1478) } \\
\text { In the era of Hindu- } \\
\text { ism, devotion, and } \\
\text { worship to God, a } \\
\text { tribute to God and } \\
\text { the good deed in } \\
\text { this world will lead } \\
\text { humans into moksa, } \\
\text { the beautiful union } \\
\text { with the Highest } \\
\text { God in heaven. This } \\
\text { is the epic of Rama- } \\
\text { yana which teaches } \\
\text { ethical values for } \\
\text { the followers and } \\
\text { religious value to- } \\
\text { wards God, human, } \\
\text { environment, and } \\
\text { country. }\end{array}$ & $\begin{array}{l}\text { Islam Era: } \\
\text { (1478-1817) } \\
\text { In the era } \\
\text { of Islam, } \\
\text { the story } \\
\text { of Rama } \\
\text { is a king } \\
\text { son called } \\
\text { Betara Guru. } \\
\text { Rama is a } \\
\text { human heir } \\
\text { of Prophet } \\
\text { Adam, be- } \\
\text { cause of that } \\
\text { we don't } \\
\text { need to wor- } \\
\text { ship him } \\
\text { because the } \\
\text { only worth } \\
\text { worshiped } \\
\text { is Allah. } \\
\end{array}$ & $\begin{array}{l}\text { Colonial Era: } \\
\text { (1817-1945) } \\
\text { (In the colonial } \\
\text { era, the beginning } \\
\text { until the end of } 19 \\
\text { century, it is a de- } \\
\text { velopment era for } \\
\text { scientific rationality } \\
\text { idea using physi- } \\
\text { cal rationality and } \\
\text { natural science. } \\
\text { At present, Rama- } \\
\text { yana engraving } \\
\text { stone is not only } \\
\text { become the empiri- } \\
\text { cal research object } \\
\text { but also used as a } \\
\text { memorandum, gift, } \\
\text { a diplomatic tool } \\
\text { with other coun- } \\
\text { tries. }\end{array}$ & $\begin{array}{l}\text { Independence Era: } \\
\text { (1945-1988) Since the 1960s realized } \\
\text { by the government for improving } \\
\text { tourism income and the exchange } \\
\text { of this country, Prambanan en- } \\
\text { gravings were opened as Rama- } \\
\text { yana Ballet Dancer's performance. } \\
\text { According to Undang-Undang } \\
\text { Negara Republik Indonesia No. } 5 \\
\text { about Cultural Heritage said that } \\
\text { it is for the sake of tourism, Rama- } \\
\text { yana was transferred into painting } \\
\text { on stone by the engraver, it is also } \\
\text { sold as house wall decoration, and } \\
\text { a framed painting as a souvenir. } \\
\text { Characters on Ramayana Epic story } \\
\text { are used as names and business } \\
\text { institutions. Furthermore, it is also } \\
\text { used as the virtuous value in the } \\
\text { society. }\end{array}$ \\
\hline
\end{tabular}


ral science works for solving life problem related to the natural environment where human lives. The universe, mountain, and forest are no more scary for humans with the mystical story of god and goddess or spirits. Nature is an object while a human is a subject, this idea is the background of natural science and physics. Humans, as the subject manages and studies while nature is the managed object and studied. This idea becomes the base on quantification positivistic research method. The law of exact science-nature and paradigm procedure in studying humans is adopted and applied for humans. This assumption affects the observed human placed as the object equal with natural things, the treatment and the research instrument adjusts to natural science experiment procedure.

Postpositivistc research for revealing human's meaning of life, cultural meaning, art meaning, or revealing beyond empirical things has been conducted in philosophy field, history of art, social, humanism, cultural study. Meanwhile, the education field seems to be stupified by the glory of the modern era; the positivistic study is still normative and focused on education study. Constructivist research studies in children, ways of thinking, critical thinking processes, critical literacy research, and deconstruction research end with an appreciation of "the other." This can be observed and respected as a friend or subject, so that the position is the same. In Javanese, he said nguwongke uwong, means to humanize humans. Postpositivistics Research can be a "tool' in revealing meaning beyond art phenomenon that has been explained in this paper with Paul Ricoeur Hermeneutica and Foucauldian discourse archeology ideas analysis. Happy developing study to form fully Indonesian human from Ontology aspect and Ontics.

\section{REFERENCES}

Benton, T. (2001). Philosophy of Social Science New York. London: Palgrave.

Foucault, M. (1976). Arkeologi Pengetahuan. Terjemahan Inyiak Ridwan Muzir. Yogyakarta: IRCiSoD.

Hardiman, F. B. (2003). Melampaui Positivisme dan Modernitas. Yogyakarta: Kanisius.

Hoed, B. H. (2011). Semiotik dan Dinamika Sosial Budaya. Yogyakarta: Komunitas Bambu.

Kali, A. (2013). Diskursus Seksualitas Michel Foucault. Flores: Ledalero.

Kholifah, S. (2018). Genealogi Sebagai Metode dan Alat Analisis Metodologi Penelitian Kualitatif Berbagi Pengalaman dari Lapangan. Jakarta: Rajawali Pers Raja Grafindo Persada.

Poespoprodjo, W. (2004). Hermeneutika. Badung: Pustaka Setia.

Poespowardojo, T. M. S. (2015). Filsafat Ilmu Pengetahuan Kritik terhadap Visi Positivisme Logis serta Implikasinya. Jakarta: Kompas.

Pradoko, A. M. S. (2015). Perubahan Pemaknaan Candi Siwa Prambanan Sejak Abad ke-9 Hingga Abad ke-20: Kajian Arkeologi Pengetahuan. Depok: Universitas Indonesia.

Purnamasari, A. R. (2018). Nilai-nilai Edukatif dan Implementasi Nyanyian Senjang Petuoh Lame di Sanggar Senjang Budayo Sekayu Kabupaten Musi Banyasin Provinsi Sumatera Selatan. Yogyakarta: Program Studi Pendidikan Seni Pascasarjana UNY.

Sulastri, R. (2016). Kajian Lagu Berita Kepada Kawan Karya Ebiet G.Ade Ditinjau dari Perspektif Hermeneutik. Yogyakarta: Pend. Seni Musik FBS UNY.

Sumartono. (2017). Metodologi Penelitian Kualitatif Seni Rupa dan Desain. Jakarta: Universitas Trisakti.

Van-Peursen, C. A. (1988). Strategi Kebudayaan. Jakarta: Kanisius. 